\title{
FOOD CHOICE MOTIVES OF GENERATION Z IN SERBIA
}

Sanja Mitic ${ }^{1}$, Semir Vehapi ${ }^{2}$

*Corresponding author E-mail: sanja@ekof.bg.ac.rs

A R T I C L E I N F O
Original Article
Received: 06 April 2020
Accepted: 28 September 2020
doi:10.5937/ekoPolj2101127M
UDC 641.3:581.166(497.11)

Keywords:

food choice motives, generation $Z$, food choice questionnaire, food marketing

JEL: M31, I10, Q18

\section{A B S T R A C T}

The topic of this paper is food choice motives of generation $\mathrm{Z}$ in Serbia. Generational cohort is used as a theoretical perspective, as the research is focusing on specific generational cohort. The aim of this research is to understand the characteristics of generation $\mathrm{Z}$ and their food choice motives. A Food Choice Questionnaire (FCQ) was used for analyzing generation Z's motives. A survey was used for data gathering. The sample consists of 287 students, from three universities from Serbia. The results are presented based on descriptive statistics, statistical testing and principal component analysis. The most important food choice motives identified are: sensory appeals, health and nutritional food attributes and convenience of preparation. The study revealed that generation $\mathrm{Z}$ in Serbia has some common features, as recognized in developed countries, but shows one interesting divergence, regarding the undervaluation of ethical factors. Managerial implications from the perspective of a marketing strategy are discussed.

(C) 2021 EA. All rights reserved.

\section{Introduction}

Food consumption patterns are rapidly changing due to various external - cultural, social and economic influences. Understanding consumers' food choice is essential not just for developing an effective marketing strategy of food producers, but also for creating successful public policies aimed at influencing health and dietary habits of population. As the research of food choice is dominant in developed countries, those results should be reconsidered not just in different cultural, but also in different economical contexts. Additional differences that should be considered are regarding generation marketing. As a generational cohort perspective has been widely used in contemporary marketing research, the aim of this study is to understand the main characteristics of

\footnotetext{
1 Sanja Mitic, Ph.D., Associate Professor, University of Belgrade, Faculty of Economics, Belgrade, Kamenicka 6, Republic of Serbia, Phone: +381698066 350, E-mail: sanja.mitic@ ekof.bg.ac.rs, ORCID ID (http://orcid.org/0000-0003-1365-273X)

2 Semir Vehapi, Ph.D., Teaching Assistant, State University of Novi Pazar, Vuka Karadzica 9, Novi Pazar, Republic of Serbia, Phone: +381 638618 381, E-mail: svehapi@np.ac.rs, ORCID ID (http://orcid.org/0000-0002-7503-6716)
} 
new generational cohort, generation $Z$. This study offers a new insight into the attitudes of the young population, generation $\mathrm{Z}$, from Serbia, regarding food choice.

The main goals of the study are: 1) to identify the main characteristics of generation Z, in regard to their general features, their consumption behavior and purchasing power potentials; and 2) to recognize the main food choice motives of generation $\mathrm{Z}$ in Serbia, 3 ) to identify main differences between respondents' attitudes in regard to their gender, family income and family size.

The analysis of consumption behavior of generational cohorts has become a rising topic in the marketing literature. The generational cohort stands for a group of people born during a particular period. Generational cohort perspective describes "a complex of social, historical, and environmental factors that simultaneously affect individuals and populations of individuals" (Yang \& Land, 2013), which can influence the way one cohort perceives and experiences events. Those differences between cohorts can cause diverse buying behaviors of consumers from different cohorts (Noble \& Schewe, 2003; Chaney et al., 2017).

The analysis of generational cohort behavior in the food marketing literature has increased in the last decade. The majority of studies examined the food preferences of millennials (people born between 1980 and 1996), or generation Y (Yepes, 2014; Marinelli et al., 2014; Thambiah et al., 2015; Faber et al., 2020; Küster et al., 2019; Molinillo et al., 2020; Kamenidou et al., 2020). As generation Y is of a significant size and purchasing power, it is not surprising that it represents the main focus of researchers. On the other hand, generation $\mathrm{Z}$ will become increasingly important in the future, as their members will start their professional careers and significantly increase their incomes. Aiming to shed light on the food choice of generation Z, firstly, it is necessary to understand the characteristics of generation $\mathrm{Z}$ and already identified buying behavior patterns.

The terms post-millennial generation or generation $\mathrm{Z}$ refer to people born between 1995 and 2012 (but still without consensus in the literature regarding the exact period). This generation is oriented toward digital technology and the Internet, they are technologically savvy, well-informed, socially responsible, tolerant and well connected (Chaney et al., 2017; Kitchen \& Proctor, 2015). They are also called Digital natives, being perceived as "native speakers of the digital language of computers, video games and the Internet" (Prensky, 2001). Most of generation Z is continuously connected through smartphones and tablets, and given that the Internet has been available to them for all their lives, they tend to be better-informed than any other generational cohort (Smith, 2019). Four general characteristics are linked to generation $\mathrm{Z}$ as consumers (Wood, 2013): 1) a focus on innovation, especially in the area of technology, expecting continuous improvements of products offered on the market; 2) a focus on convenience of product attributes and experience, product delivery, and marketing communications; 3) a focus on security, while growing up in economically difficult times, they feel more cautious about spending their money, thus expressing low level of brand loyalty 
and 4) a tendency toward escapism, as they temporally express desire to escape the reality facilitated by the emergence of video-games, social media and smart mobile devices. Smart technologies have a significant influence on generation $Z$ consumers' experiences, as they see them as an instrument for being well-informed, for making autonomous decisions, increasing convenience and efficiency of market transactions (Priporas et al., 2017). In regard to their characteristics and lifestyle this generation is described as "new conservatives" that highly appreciate traditional values such as respect, trust, family, savings, responsibility and independency (Williams \& Page, 2011; Williams et al., 2010).

According to Forbes data, generation $\mathrm{Z}$ accounts for up to $\$ 143$ billion in direct spending in the USA, with additional high indirect impact on the consumption of households, while in $93 \%$ of cases children influence the household purchases (Fromm, 2018). In the study from 2011, Williams and Page highlighted high spending of teenagers, in that time the first representatives of generation $Z$, which was $\$ 43$ billion with additional influence on family spending of approximately $\$ 600$ billion. They stated that kids influenced more than $70 \%$ of family food choices and $80-90 \%$ of choices of products for kids (Williams \& Page, 2011).

As they regularly use the Internet and smart gadgets, their behavior is often examined in the context of their retail habits (Priporas et al., 2017; Dabija \& Lung, 2019; Marjanen et al., 2019; Lissitsa \& Kol, 2019) and marketing communication (Kitchen \& Proctor, 2015; Smith, 2019), especially regarding the usage and influence of social media. The issue of food choice of generation $\mathrm{Z}$ has not been widely examined. There are some findings that this generation expresses more interest in environmental issues and sustainable consumption (Chaney et al., 2017; Kitchen \& Proctor, 2015; Kamenidou et al., 2019). The young generation is concerned with environmental issues, expressing strong positive attitudes and purchasing intentions toward green environmental products (Kanchanapibul et al., 2014) or green-oriented retail stores (Dabija, 2018). In order to fulfill the identified gap, this study investigates food choice motives of generation $\mathrm{Z}$ in Serbia.

The paper is structured in four parts. After the introduction, where the main characteristics of generation $\mathrm{Z}$ are discussed, the methodological issues of the research will be presented, with a focus on Food choice questionnaire, widely used for analyzing main consumers' food buying motives. In part three, the main results of the research are presented and discussed, after which the most important outcomes are summarized, with managerial implications and proposals for further research.

\section{Materials and methods}

The Food choice questionnaire (FCQ) was used as a tool for gathering data about the food preferences of generation Z. FCQ, consisting of 36 variables, was proposed by Steptoe, Pollard and Wardle (1995). All variables describing food buying motives can be grouped in nine dimensions: health, mood, convenience, sensory appeal, natural 
content, price, weight control, familiarity and ethical concern. This questionnaire is a widely used tool for analyzing main consumers' motives for buying food products. One recent study explored its validity and reliability in 9 European countries (Markovina et al., 2015), concluding that FCQ is an appropriate tool for exploring food choice motives among European population, although except from Poland, all the analyzed countries were developed ones. FCQ was used and tested in Serbia and other developing countries from the South-East Europe region (Milošević et al., 2012; Gagić et al., 2014). In neither study were the original nine factors identified. Gagić et al. (2014), recognized eleven dimensions of food choice motives of Serbian consumers. Along with the original nine dimensions, the two additional were: the availability of food and food image. The analysis of Milošević et al. (2012), conducted in six Western Balkan countries, revealed eight dimensions, with some significant differences compared to the original model, indicating "that Steptoe et al.'s (1995) nine-factorial design displays suboptimal fit for the West Balkan Countries." Both studies identified sensory appeal, health and availability/purchase convenience as main food choice motives of consumers from Serbia/Western Balkan countries (Milošević et al., 2012; Gagić et al., 2014).

A survey conducted during 2019, within a sample of 287 students from three universities from Serbia, was used for collecting the data. Students who participated in the research were enrolled in the third or fourth year of studies, which means that they were born in 1997 or 1998 . The structure of the sample is presented in Table 1. The results are presented based on descriptive statistics, statistical testing and principal component analysis.

Table 1. The structure of the sample

\begin{tabular}{|c|c|c|c|}
\hline \multicolumn{2}{|c|}{ Characteristics of respondents } & \multirow{2}{*}{\begin{tabular}{|l}
$\begin{array}{l}\text { Number of } \\
\text { respondents }\end{array}$ \\
287
\end{tabular}} & \multirow{2}{*}{$\begin{array}{l}\% \text { of respondents } \\
100 \%\end{array}$} \\
\hline & Total & & \\
\hline \multirow{2}{*}{ Gender } & Female & 198 & 70 \\
\hline & Male & 85 & 30 \\
\hline \multirow{4}{*}{ Location } & Large city & 108 & 38.2 \\
\hline & Suburb of a large city & 43 & 15.2 \\
\hline & Medium or small city & 97 & 34.3 \\
\hline & Rural area & 35 & 12.4 \\
\hline \multirow{6}{*}{$\begin{array}{l}\text { Household } \\
\text { income }\end{array}$} & No income & 4 & 1.5 \\
\hline & Less than $50.000 \mathrm{rsd}$ & 40 & 14.9 \\
\hline & Between 50.000 and 100.000 rsd & 95 & 35.3 \\
\hline & Between 100.000 and 150.000 rsd & 70 & 26 \\
\hline & Between 150.000 and 200.000 rsd & 34 & 12.6 \\
\hline & More than 200.000 rsd & 26 & 9.7 \\
\hline \multirow{6}{*}{$\begin{array}{l}\text { Size of a } \\
\text { household }\end{array}$} & Two members & 16 & 5.7 \\
\hline & Three members & 47 & 16.8 \\
\hline & Four members & 117 & 41.8 \\
\hline & Five members & 57 & 20.4 \\
\hline & Six members & 27 & 9.6 \\
\hline & Other & 16 & 5.7 \\
\hline
\end{tabular}




\section{Results and discussions}

Based on the Food Choice Questionnaire (Steptoe et al. 1995), the main determinants of food choice were recognized. The 36 items from the original FCQ were evaluated on 5-item Likert scale. In Table 2, the individual items with above average score (more than 3.596) are listed. Apart from the sensory criteria, such as taste, texture and smell of the food, health and natural characteristics and motives connected with convenience are the most important. Sensory appeals are expected to be important, in majority of the research of food choice in foreign countries and in Serbia (Steptoe et al. 1995; Eertmans et al., 2006; Januszewska et al., 2011; Markovina et al., 2015; Milošević et al., 2012; Gagić et al., 2014).

Table 2. Main food choice motives

\begin{tabular}{|l|l|l|l|}
\hline & Food choice motives & Mean & Std. deviation \\
\hline 1 & Tastes well & 4.7003 & 0.62082 \\
\hline 2 & Is good value for money & 4.3275 & 0.83877 \\
\hline 3 & Is nutritious & 4.2753 & 0.80916 \\
\hline 4 & Has a pleasant texture & 4.2622 & 0.82363 \\
\hline 5 & Keeps me healthy & 4.2334 & 0.85558 \\
\hline 6 & Is easily available in shops and supermarkets & 4.1568 & 0.89275 \\
\hline 7 & Smells nice & 4.0801 & 0.99502 \\
\hline 8 & Is good for my skin/teeth/hair/nails etc. & 4.0594 & 0.95143 \\
\hline 9 & Makes me feel good & 4.0105 & 0.91185 \\
\hline 10 & Contains natural ingredients & 3.9895 & 0.88208 \\
\hline 11 & Contains a lot of vitamins and minerals & 3.9443 & 0.85097 \\
\hline 12 & Cheers me up & 3.9408 & 1.02758 \\
\hline 13 & Can be cooked very easily & 3.8451 & 0.99323 \\
\hline 14 & Keeps me awake/alert & 3.8287 & 0.95624 \\
\hline 15 & Can be bought in shops close to where I live or work & 3.8049 & 1.08240 \\
\hline 16 & Is easy to prepare & 3.7770 & 1.04401 \\
\hline 17 & Is high in protein & 3.7657 & 0.98284 \\
\hline 18 & Contains no artificial ingredients & 3.6794 & 1.00438 \\
\hline 19 & Takes no time to prepare & 3.6794 & 1.02846 \\
\hline
\end{tabular}

On the second place is whether an item Is good value for money, which can be explained by the already recognized buying preferences of generation $\mathrm{Z}$, as they value security and feel more cautious about spending their money (Wood, 2013). This generation is seen as "new conservatives" (Williams \& Page, 2011) not just as they embody the traditional beliefs and values, but responsible consumption, too. Among 19 items with above average scores, the majority reflect health and natural characteristics of food: Is nutritious, Keeps me healthy, Is good for my skin/teeth/hair/nails etc., Contains natural ingredients, Contains a lot of vitamins and minerals, Is high in protein, Contains no artificial ingredients. This result can indicate high concerns of young consumers for health effects of food and their health in general. The third important group of motives consists of the following: Is easily available in shops and supermarkets, Can be cooked very easily, Can be bought in shops close to where I live or work, Is easy to 
prepare, Takes no time to prepare. All the listed criteria are connected to convenience, in food preparation and food purchasing. As already discussed, generation $\mathrm{Z}$ is seen as a generation oriented toward convenience regarding product experience and product delivery (Wood, 2013).

Motives with the lowest score (less than 3) were: Is packaged in an environmentally friendly way (2.9373), Is low in calories (2.8676), Is like the food I ate when I was a child (2.8007), Has the country of origin clearly marked (2.7143), and Comes from countries I approve of politically (1.8223). Having such low marks for environmental aspects of the product is somewhat unexpected, since the ecological responsibility was recognized as one of the important characteristic of generation $\mathrm{Z}$. On the other hand, there is a recent study conducted in Croatia, with similar findings concerning the attitudes of young consumers toward sustainability and ecological issues (Razum et al., 2017).

In the next part, the differences in food buying motives in regard to gender, income and family size of respondents were analyzed. Food buying motives of male and female respondents were found to be significantly different in several items. In general, female respondents gave higher average marks to majority of items, as already recognized in the literature (Januszewska et al., 2011; Steptoe et al., 1995), even to those connected to sensory appeals and convenience of preparation. For example, male respondents gave higher average marks to following items: Comes from countries I approve of politically, Is high in protein, Helps me relax and Is cheap. But, only in case of protein content there is statistically significant difference $(\mathrm{t}=2.034, \mathrm{p}=0.043)$. Higher average mark for protein content of male respondents $(\mathrm{M}=3.9647)$ can be explained by their higher interest in fitness performances, especially regarding strength training, compared to women $(\mathrm{M}=3.7107)$. On the other hand, women are more concerned with the items listed in Table 3, with statistically significant differences.

Table 3. Food choice - gender differences

\begin{tabular}{|l|l|l|l|l|}
\hline & \multicolumn{2}{|c|}{ Mean } & \multirow{2}{*}{ t } & \multirow{2}{*}{ Sig. (2-tailed) } \\
\hline & \multicolumn{1}{|c|}{ Female } & \multicolumn{1}{|c|}{ Male } & & \\
\hline Tastes well & 4.7475 & 4.5765 & -2.126 & .034 \\
\hline Is low in calories & 3.0000 & 2.5529 & -2.923 & .004 \\
\hline Is low in fat & 3.3081 & 2.9647 & -2.329 & .021 \\
\hline Cheers me up & 4.0556 & 3.6824 & -2.819 & .005 \\
\hline Smells nice & 4.2273 & 3.7176 & -4.055 & .000 \\
\hline Can be cooked very easily & 3.9242 & 3.6506 & -2.132 & .034 \\
\hline Has a pleasant texture & 4.3299 & 4.1059 & -2.098 & .037 \\
\hline Keeps me awake/alert & 3.9040 & 3.6548 & -2.025 & .044 \\
\hline Looks nice & 3.6212 & 3.2941 & -2.341 & .020 \\
\hline $\begin{array}{l}\text { Is good for my skin/teeth/hair/nails } \\
\text { etc. }\end{array}$ & 4.1616 & 3.8333 & -2.676 & .008 \\
\hline Makes me feel good & 4.0914 & 3.8471 & -2.080 & .038 \\
\hline
\end{tabular}


In case of income of the household, major differences in the attitudes of respondents were not found (there is an indication of differences regarding price: It is not expensive $(\mathrm{F}=1.955, \mathrm{p}=0.086))$. As for household size, there are differences regarding convenience of preparation: Can be cooked very easily $(\mathrm{F}=3.441, \mathrm{p}=0.005)$ and $I$ s easy to prepare $(\mathrm{F}=2.283, \mathrm{p}=0.047)$. Respondents from smaller households were more concerned for these two items. Statistically significant differences were found regarding concerns with political aspects and the country of origin, but as those criteria were valued with the lowest average marks, those differences will not be commented additionally.

The following step was the principal component analysis, performed with varimax rotation. Kaiser-Meyer-Olkin Measure verified the sampling adequacy, with KMO = 0.825, which is above the acceptable limit. Bartlett's Test of Sphericity Approx. ChiSquare $=3638.894, \mathrm{p}=0.000$, indicated that correlations between the items were sufficiently large. Nine factors were considered significant. They account for $61,104 \%$ of the variance. Table 4 shows the factor loadings after rotation. Factor loadings over .40 appear in bold. Majority of the items have value higher than .60. The items that cluster on the same components suggest following nine components: Health, Mood, Convenience of preparation, Sensory appeal, Weight control, Availability, Familiarity, Ethical concern and Natural content. As two factors (Natural content and Familiarity) are composed of only two items, it was not surprising that those two items have low reliability (less than .60).

Table 4. Exploratory factor analysis results

\begin{tabular}{|c|c|}
\hline & Factor loadings \\
\hline & $\begin{array}{r}\text { Health } \\
\text { Chronbach's alpha } 0.85 \\
\end{array}$ \\
\hline Contains a lot of vitamins and minerals & .769 \\
\hline Keeps me healthy & .767 \\
\hline Is good for my skin/teeth/hair/nails etc. & .727 \\
\hline Is high in protein & .716 \\
\hline Keeps me awake/alert & .619 \\
\hline Is high in fibers & .546 \\
\hline Contains no artificial ingredients & .545 \\
\hline \multirow[t]{2}{*}{ Is nutritious } & .500 \\
\hline & $\begin{array}{r}\text { Mood } \\
\text { Chronbach's alpha } 0.80 \\
\end{array}$ \\
\hline Helps me cope with stress & .802 \\
\hline Helps me relax & .789 \\
\hline Helps me cope with life & .700 \\
\hline Cheers me up & .642 \\
\hline \multirow[t]{2}{*}{ Makes me feel good } & .581 \\
\hline & $\begin{array}{r}\text { Convenience of preparation } \\
\text { Chronbach's alpha } 0.83 \\
\end{array}$ \\
\hline Can be cooked very easily & .852 \\
\hline Takes no time to prepare & .831 \\
\hline Is easy to prepare & .805 \\
\hline
\end{tabular}




\begin{tabular}{|c|c|}
\hline & Factor loadings \\
\hline & $\begin{array}{r}\text { Sensory appeal } \\
\text { Chronbach's alpha } 0.71\end{array}$ \\
\hline Tastes well & .770 \\
\hline Smells nice & .727 \\
\hline Has a pleasant texture & .669 \\
\hline Looks nice & .488 \\
\hline \multirow[t]{2}{*}{ Is good value for money } & .399 \\
\hline & $\begin{array}{r}\text { Weight control } \\
\text { Chronbach's alpha } 0.76 \\
\end{array}$ \\
\hline Is low in calories & .808 \\
\hline Is low in fat & .740 \\
\hline \multirow[t]{2}{*}{ Helps me control my weight } & .686 \\
\hline & $\begin{array}{l}\text { lity - price and distribution } \\
\text { Chronbach's alpha } 0.66\end{array}$ \\
\hline Is cheap & .711 \\
\hline Is not expensive & .704 \\
\hline Can be bought in shops close to where I live or work & .679 \\
\hline \multirow[t]{2}{*}{ Is easily available in shops and supermarkets } & .395 \\
\hline & $\begin{array}{r}\text { Familiarity } \\
\text { Chronbach's alpha } 0.56\end{array}$ \\
\hline Is what I usually eat & .712 \\
\hline \multirow[t]{2}{*}{ Is familiar } & .649 \\
\hline & $\begin{array}{r}\text { Ethical concern } \\
\text { Chronbach's alpha } 0.63 \\
\end{array}$ \\
\hline Comes from countries I approve of politically & .677 \\
\hline Is like the food I ate when I was a child & .592 \\
\hline Has the country of origin clearly marked & .554 \\
\hline \multirow[t]{2}{*}{ Is packaged in an environmentally friendly way } & .512 \\
\hline & $\begin{array}{r}\text { Natural content } \\
\text { Chronbach's alpha } 0.50 \\
\end{array}$ \\
\hline Contains no additives & .641 \\
\hline Contains natural ingredients & .521 \\
\hline
\end{tabular}

The results do not correspond to Steptoe's et al. (1995) nine-factor model, as some variation was recognized, compared to the original model. The original model was found to be only partially applicable to Serbian generation $Z$. The main difference is regarding three motives: Availability, Price and Convenience. In this research, the convenience of preparation emerged as an individual factor (as in Milošević et al., 2012), while distribution availability was in the group with the price criteria. Compared to other researches conducted in Serbia, there are differences, given that those studies reported eight-factor (Milošević et al., 2012) or eleven-factor (Gagić et al., 2014) model.

In Table 5, average marks for identified nine factors (but not in line with original ninefactor model) are summarized. The results confirm that the most important food buying motives are Sensory appeals $(M=4.1425)$, Health $(M=3.8895)$ and Convenience of preparation $(M=3.7676)$. The first two motives are in accordance with the previous 
studies conducted in Serbia (Milošević et al., 2012; Gagić et al., 2014). Convenience of preparation emerged as an important motive to generation $\mathrm{Z}$, which has already been discussed in terms of their orientation toward efficiency and convenience of brand or product experience. As their parents, generation X cohort, were heavy users of convenience goods, this consumption pattern is widely present in their children, generation Z (Wood, 2013). In case of food consumption, for generation Z in Serbia, the main issue is regarding convenience in product time-saving attribute and in brand experience, such as being easy to cook. The next two factors, with above average marks, are Natural content $(\mathrm{M}=3.6825)$ and Availability (in terms of price and distribution, $\mathrm{M}=3.6285$ ). As Availability contains items related to price and distribution, these results need additional clarification, based on an individual items score. Two availability items, Can be bought in shops close to where I live or work and Is easily available in shops and supermarkets, have larger score than two price items: Is cheap and Is not expensive. As generation $\mathrm{Z}$ expresses positive attitudes toward convenience in terms of delivery, such result is expected. The least important factor is Ethical concerns, which is in line with some studies from the region (Cerjak et al. 2014; Razum et al., 2017), but not expected in case of generation $\mathrm{Z}$, which is often described as an environmentally responsible cohort, highly interested in political issues.

Table 5. Mean values for each factor

\begin{tabular}{|l|l|l|}
\hline Factors & Mean & Std. Deviation \\
\hline Sensory appeal* & 4.1425 & 0.64992 \\
\hline Health & 3.8895 & 0.64209 \\
\hline Convenience of preparation & 3.7676 & 0.88435 \\
\hline Natural content & 3.6825 & 0.80056 \\
\hline Availability - price and distribution & 3.6285 & 0.69765 \\
\hline Mood & 3.5121 & 0.81284 \\
\hline Familiarity & 3.4826 & 0.90049 \\
\hline Weight control & 3.1661 & 0.97037 \\
\hline Ethical concern & 2.5726 & 0.78847 \\
\hline "Item Is good value for money was not calculated within this factor & \\
\hline
\end{tabular}

Examining the differences between groups of respondents based on calculated scores of nine factors, two variables were found to be relevant: gender and household size. In case of gender, two statistically significant differences appeared, with regard to Sensory appeals $(\mathrm{t}=-3.739, \mathrm{p}=0.000)$ and Weight control $(\mathrm{t}=-2.784, \mathrm{p}=0.006)$. Female respondents valued both factors with higher average marks than male respondents. Apart from motives connected to weight control which has already been recognized in the literature (Januszewska et al., 2011), it is interesting that Sensory appeal is more important to female than male respondents. These results are not in line with the previous research of food buying motives that considered the role of gender (Goktolga et al., 2006; Fotopoulos et al., 2009; Ares \& Gámbaro, 2007; Szakály et al., 2018, Gagić et al., 2014). On the other hand, the previous studies found significant differences regarding health motives, which did not appear in this case (Steptoe et al., 1995; Szakály et al., 2018). 
In case of the size of households, there are statistically significant differences regarding Sensory appeals $(\mathrm{t}=2.929, \mathrm{p}=0.014)$ and Convenience of preparation $(\mathrm{t}=3.013$, $\mathrm{p}=0.012$ ). Sensory appeals are more important to respondents who come from larger households (five and six members), while Convenience of preparation is more important to respondents who came from smaller households (two and three members), which is surprising at first glance. But, in smaller households (two or three members), younger family members (as our respondents are) can be more engaged in food preparation.

The main managerial implication for food producers that target generation $\mathrm{Z}$ is related to the redesigning of a marketing mix, in terms of: 1) developing products with clear health and nutritional benefits, avoiding artificial ingredients and increasing the convenience of preparation and consummation; 2) marketing communication focusing on main consumer motives, 3) increasing delivery efficiency and 4) a value based price strategy. The functional food producers and organic food producers can expect that their products fit generation Z's preferences, but they have to develop convenience food formats and adjust other marketing mix instruments. The discussion on generation Z's preferences of functional and organic food may be an interesting topic for further research.

Main proposals for future research could be regarding preferred delivery channels and attitudes toward online channels for food products, which can significantly increase their availability. The finding of the research not in line with the consumption patterns of generation $\mathrm{Z}$ is that the respondents from Serbia undervalue the importance of ethical factors, such as political and environmental concerns. These results need further, more detailed examination, which could be additional proposal for further studies on this topic. A key methodological issue to address in further research of this topic should be the size of the sample, which is the main limitation of this research. For testing the validity and reliability of the Food choice questionnaire, it is essential to significantly increase sample size.

\section{Conclusions}

This paper deals with food choice motives of generation $\mathrm{Z}$ in Serbia. This generation cohort of young consumers has become increasingly interesting for researchers and companies as their purchasing power rises. Generation $\mathrm{Z}$ has been recognized as a generation of digital natives, technologically superior, well-informed and wellconnected. They are seen as responsible customers, oriented toward convenience and security, environmentally concerned, choosing high value-for-money offers over brand loyalty. Recognizing different behavioral patterns, in terms of their purchasing and consuming habits, the aim of this paper was to analyze main food choice motives of generation Z, which has not been investigated much in the literature. For that purpose, Steptoe's et al. (1995) Food choice questionnaire was used. Although the original ninefactor model was not found to be applicable in this case, this study revealed major food motives of generation $\mathrm{Z}$ in Serbia. Apart from sensory appeals, this generation is highly interested in health benefits of food products and convenience of preparation. Additional two important factors are natural content and the availability of food products, in terms 
of price and distribution. An individual motives' scores highlight the importance of value based perspective for generation $Z$. They undervalue items regarding low prices of food products, but highly appreciate food products that offer good value for money. Such results are in accordance with the previous findings about generation $\mathrm{Z}$ consumption behaviors. The differences in the attitudes of the respondents were also identified, in regard to their gender and household size, which can be addressed in the market segmentation process. This study offered valuable managerial implications for creating effective marketing strategy of the food producers that target generation $\mathrm{Z}$.

\section{Acknowledgements}

The paper is a part of the research done within the project number 179062 and project number 41030, financed by the Ministry of Education, Science and Technological Development of the Republic of Serbia.

\section{Conflict of interests}

The authors declare no conflict of interest.

\section{References}

1. Ares, G., \& Gámbaro, A. (2007). Influence of gender, age and motives underlying food choice on perceived healthiness and willingness to try functional foods. Appetite, 49(1), 148-158. https://doi.org/10.1016/j.appet.2007.01.006

2. Cerjak, M., Haas, R., Brunner, F., \& Tomić, M. (2014). What motivates consumers to buy traditional food products? Evidence from Croatia and Austria using word association and laddering interviews. British Food Journal, 116(11), 1726-1747. https://doi.org/10.1108/bfj-02-2014-0090

3. Chaney, D., Touzani, M., \& Ben Slimane, K. (2017). Marketing to the (new) generations: summary and perspectives. Journal of Strategic Marketing, 25(3), 179-189. https://doi.org/10.1080/0965254x.2017.1291173

4. Dabija, D.C. (2018). Enhancing green loyalty towards apparel retail stores: A cross-generational analysis on an emerging market. Journal of Open Innovation: Technology, Market, and Complexity, 4(8), https://doi.org/10.1186/s40852-0180090-7

5. Dabija, D.C., \& Lung, L. (2019). Millennials Versus Gen Z: Online Shopping Behaviour in an Emerging Market. Springer Proceedings in Business and Economics, 1-18. https://doi.org/10.1007/978-3-030-17215-2_1

6. Eertmans, A., Victoir, A., Notelaers, G., Vansant, G., \& Van den Bergh, O. (2006). The Food Choice Questionnaire: Factorial invariant over western urban populations? Food Quality and Preference, 17(5), 344-352. https://doi. $\operatorname{org} / 10.1016 /$ j.foodqual.2005.03.016 
7. Faber, I., Castellanos Feijoó, N.A., Van de Sompel, L., Davydova, A., \& PerezCueto, F.J.A. (2020). Attitudes and knowledge towards plant-based diets of young adults across four European countries. Exploratory survey. Appetite, 145, 104498. https://doi.org/10.1016/j.appet.2019.104498

8. Fotopoulos, C., Krystallis, A., Vassallo, M., \& Pagiaslis, A. (2009). Food Choice Questionnaire (FCQ) revisited. Suggestions for the development of an enhanced general food motivation model. Appetite, 52(1), 199-208. https://doi.org/10.1016/j. appet.2008.09.01

9. Fromm, J. (2018). How much financial influence does Gen $Z$ have? Retrieved from www.forbes.com/sites/jefffromm/2018/01/10/what-you-need-to-know-about-thefinancial-impact-of-gen-z-influence/\#2e2f76c656fc (February 29, 2020).

10. Gagić, S., Jovičić, A., Tešanović, D. „\& Kalenjuk, B. (2014). Motives for food choice among Serbian consumers. Economics of agriculture, 61(1), 41-51. https:// doi.org/10.5937/ekoPolj1401041G

11. Goktolga, Z.G., Bal, S.G., \& Karkacier, O. (2006). Factors effecting primary choice of consumers in food purchasing: The Turkey case. Food Control, 17(11), 884-889. https://doi.org/10.1016/j.foodcont.2005.06.006

12. Januszewska, R., Pieniak, Z., \& Verbeke, W. (2011). Food Choice Questionnaire revisited in four countries. Does it still measure the same? Appetite, 57(1), 94-98. https://doi.org/10.1016/j.appet.2011.03.014

13. Kamenidou, I., Mamalis, A.S., Pavlidis, S., \& Bara, E.Z. (2019). Segmenting the Generation Z Cohort University Students Based on Sustainable Food Consumption Behavior: A Preliminary Study. Sustainability, 11(3). https://doi.org/10.3390/ su11030837

14. Kamenidou, I., Stavrianea, A. \& Bara, E.Z. (2020). Generational Differences toward Organic Food Behavior: Insights from Five Generational Cohorts. Sustainability, 12(6). https://doi.org/10.3390/su12062299

15. Kanchanapibul, M., Lacka, E., Wang, X., \& Chan, H. K. (2014). An empirical investigation of green purchase behaviour among the young generation. Journal of Cleaner Production, 66, 528-536. https://doi.org/10.1016/j.jclepro.2013.10.062

16. Kitchen, P. \& Proctor, T. (2015). Marketing communications in a post-modern world. Journal of Business Strategy, 36(5), 34-42. https://doi.org/10.1108/JBS-062014-0070

17. Küster, I., Vila, N., \& Sarabia, F. (2019). Food packaging cues as vehicles of healthy information: Visions of millennials (early adults and adolescents). Food Research International, 119, 170-176. https://doi.org/10.1016/j.foodres.2019.01.051

18. Lissitsa, S., \& Kol, O. (2019). Four generational cohorts and hedonic m-shopping: association between personality traits and purchase intention. Electronic Commerce Research. https://doi.org/10.1007/s10660-019-09381-4 
19. Marinelli, N., Fabbrizzi, S., Alampi Sottini, V., Sacchelli, S., Bernetti, I., \& Menghini, S. (2014). Generation Y, wine and alcohol. A semantic differential approach to consumption analysis in Tuscany. Appetite, 75, 117-127. https://doi. org/10.1016/j.appet.2013.12.013

20. Marjanen, H., Kohijoki, A.M., Saastamoinen, K., \& Engblom, J. (2019). Old dogs learning new tricks? The effect of age and generation on shopping behaviour. The International Review of Retail, Distribution and Consumer Research, 29(5), 549567. https://doi.org/10.1080/09593969.2019.1664613

21. Markovina, J., Stewart-Knox, B.J., Rankin, A., Gibney, M., de Almeida, M.D.V., Fischer, A Kuznesof, A.S., Poínhos, R., Panzone, L. \& Frewer, L. J. (2015). Food4Me study: Validity and reliability of Food Choice Questionnaire in 9 European countries. Food Quality and Preference, 45, 26-32. https://doi. org/10.1016/j.foodqual.2015.05.002

22. Milošević, J., Žeželj, I., Gorton, M., \& Barjolle, D. (2012). Understanding the motives for food choice in Western Balkan Countries. Appetite, 58(1), 205-214. https://doi.org/10.1016/j.appet.2011.09.012

23. Molinillo, S., Vidal-Branco, M., \& Japutra, A. (2020). Understanding the drivers of organic foods purchasing of millennials: Evidence from Brazil and Spain. Journal of Retailing and Consumer Services, 52, 1-9. https://doi.org/10.1016/j. jretconser.2019.101926

24. Noble, S.M., \& Schewe, C.D. (2003). Cohort segmentation. An exploration of its validity. Journal of Business Research, 56, 979-987.

25. Prensky, M. (2001). Digital Natives, digital immigrants part 1. On the Horizon, 9(5), 1-6. https://doi.org/10.1108/10748120110424816

26. Priporas, C.V., Stylos, N., \& Fotiadis, A.K. (2017). Generation Z consumers' expectations of interactions in smart retailing: A future agenda. Computers in Human Behavior, 77, 374-381. https://doi.org/10.1016/j.chb.2017.01.058

27. Razum, A., Pandža, B.I., \& Zekić, Z., (2017). The analysis of the sustainable consumption patterns of generation $\mathrm{Z}$ in fashion industry. Ekonomski pregled, 68(3), 297-318.

28. Smith, K.T. (2019). Mobile advertising to Digital Natives: preferences on content, style, personalization, and functionality. Journal of Strategic Marketing, 27(1), 6780. https://doi.org/10.1080/0965254X.2017.1384043

29. Steptoe, A., Pollard, T.M., \& Wardle, J. (1995). The development of a measure of the motives underlying the selection of food: the Food Choice Questionnaire. Appetite, 25(3), 267-284. https://doi.org/10.1006/appe.1995.0061

30. Szakály, Z., Kontor, E., Kovács, S., Popp, J., Pető, K., \& Polereczki, Z. (2018). Adaptation of the Food Choice Questionnaire: the case of Hungary. British Food Journal, 120(7), 1474-1488, https://doi.org/10.1108/BFJ-07-2017-0404 
31. Thambiah, S., Khin, A.A., Muthaiyah, S., \& Yen, Y.Y. (2015). Organic food consumption among generation $\mathrm{Y}$ in Malaysia: a conceptual framework. Journal of Applied Sciences, 15(3), 570-575. https://doi.org/10.3923/jas.2015.570.575

32. Williams, K.C., \& Page, R.A. (2011). Marketing to the generations. Journal of Behavioral Studies in Business, 5(1), 1-17.

33. Williams, K.C., Page, R.A., Petrosky, A.R., \& Hernandez, E.H. (2010). Multigenerational marketing: descriptions, characteristics, lifestyles and attitudes. Journal of Applied Business and Economics, 11(2), 21-37.

34. Wood, S. (2013). Generation $Z$ as consumers: Trends and innovation. Institute for Emerging Issues, NC State University. Retrieved from https://iei.ncsu.edu/wpcontent/uploads/2013/01/GenZConsumers.pdf (February 27, 2020).

35. Yang, Y., \& Land, C.K. (2013). Age-Period-Cohort Analysis: New Models, Methods, and Empirical Applications. Taylor \& Francis Group, Boca Raton.

36. Yepes, M.F. (2014). Mobile Tablet Menus: Attractiveness and Impact of Nutrition Labeling Formats on Millennials' Food Choices. Cornell Hospitality Quarterly, 56(1), 58-67. https://doi.org/10.1177/1938965514546371 